\title{
The Role of Multinational Enterprises in Achieving Sustainable Development - The Case of Huawei
}

\author{
Sue Claire Berning ${ }^{1}$
}

\begin{abstract}
The aim of this paper is to investigate the relationship between business and sustainable development, particularly the role of multinational enterprises (MNEs) as possible driving force for achieving sustainability. By following an inductive case study approach and referring to the Sustainable Development Goals (SDGs) of the United Nations, the sustainable undertakings of the Chinese MNE Huawei are explored. Published data on Huawei's website and online resources like annual reports, news announcements, sustainability and corporate social responsibility reports are used for this purpose. The main findings indicate that Huawei can promote sustainable development internationally on three different levels: (1) products/services, (2) business operations and (3) social contributions. Based on these findings, a systematic framework is derived to help illustrate possible and classify existing MNE's sustainability activities, as well as the related main stakeholders. This paper is useful for scholars and practitioners alike as it shows the compatibility of success in business with sustainability, as well as the potential of MNEs to contribute to sustainable development.
\end{abstract}

Keywords: Sustainable Development Goals, business, multinational enterprises, emerging markets

\section{Business and Sustainable Development}

Business and sustainability have been viewed for a long time as two completely isolated and even contradicting concepts. On the one side for doing business successfully, factors like profit generation, cost-efficiency, or return on investment are crucial. Sustainability on the other side was only understood as important aspect for the future of environmental protection (Siegel, 2009; Orlitzky, Schmidt \& Rynes, 2003). However, common reference points, intersections or interdependencies of these two concepts were unknown and not in the focus of interest.

Even though John Elkington came up with his "triple bottom line" in 1997, it took around another ten years before the academic discussion about companies' sustainability commenced (Milne \& Gray, 2013). Since then, some scholars and business people alike assert that embracing sustainability as a key strategy can lead to essential competitive advantages and might be crucial for survival (Rodriguez, Ricart \& Sanchez, 2002). Nevertheless, the question of whether sustainability undermines or improves financial results is strongly debated (Eccles \& Serafeim, 2013; Bryson \& Lombardi, 2009; Hart, 1995). Critics of sustainability argue that it just destroys shareholder value (Hall, Daneke \& Lenox, 2010; Jensen, 2010). The perceived incompatibility of business practices and sustainability coupled with the necessary large-scale change of and the long-term investment into a company's core are reasons why the commitment to sustainability cannot be regarded as commonly applied business practice (Ambec \&Lanoie, 2008).

Still, the relationship between business and sustainability has not been fully explored yet. The United Nations Development Programme (UNDP) clearly states that business, and

| 1 Senior Research and Teaching Associate at the Business School of the Technical University Ingolstadt, Germany 
in particular, multinational enterprises (MNEs) of the private sector have the potential to be catalysts and accelerators of sustainable development around the world. In 2008, the United Nations launched the initiative "Business Call to Action" (BCtA) to help advance core business activities that are inclusive of poor populations, and contribute to the achievement of sustainable development (https://www.businesscalltoaction.org/). All BCtA member companies recognize that inclusive business drives innovation, builds markets, strengthens supply chains, and improves sustainable earnings and empowerment among the poor.

\section{Sustainable Development Goals (SDGs) and Multinational Enterprises (MNEs)}

The SDGs are 17 global goals set by the United Nations in 2015 (www.un.org/sustainabledevelopment/sustainable-development-goals/). They comprise a plan of action with the aim to end poverty, protect the planet and ensure that all people enjoy peace and prosperity (see Figure 1).

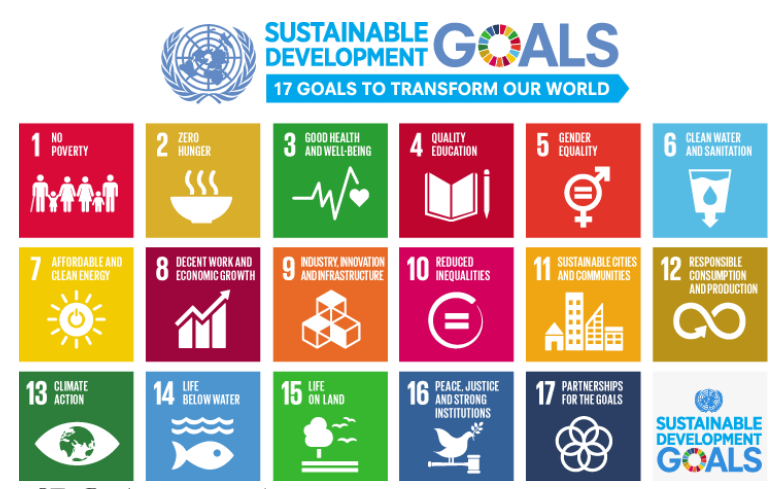

Figure 1: Overview of 17 SDGs (www.un.org)

All 193 Member States of the United Nations adopted this plan and agreed on mobilizing efforts to promote strategies that build economic growth and address a range of social needs including education, health, social protection, and job opportunities while tackling climate change and environmental protection (www.undp.org/content/undp/en/home/sustainable-development-goals.html). The SDGs provide clear guidelines to make appropriate choices to improve life, in a sustainable way, for future generations. As the SDGs are not legally binding, national governments should take ownership and establish frameworks for the achievement of the 17 goals. In addition, civil society, business, higher education and citizens need to be involved in addressing the current complex social, economic, and environmental challenges (www.unsdsn.org).

As the SDGs define global sustainable development priorities and explicitly call on all business to apply their innovation to solve sustainable development challenges, they are considered as opportunities for business-led solutions and technologies as companies can demonstrate how their business can help to advance sustainable development (www.sdgcompass.org). 
Specifically MNEs can contribute to the achievement of sustainable development as their management decisions have economic, social and environmental consequences on an international scale. Sustainability understood as development that meets the needs of the present without comprising the ability of future generations to meet their own needs means for MNEs that they have to act responsibly in all of these three areas.

Regarding economic repercussions, MNEs are important agents for promoting economic growth through creating jobs, generating income, complementing domestic savings, transferring technology, increasing competition, and stimulating entrepreneurship (Oetzel \& Doh, 2009; Lowe \& Kenney, 1999). As to social developments, MNEs can help increase local knowledge and skills, improve safety standards, cooperate with local organizations, alleviate poverty, and by linking different countries through trade and business promote world peace (Kolk, 2016; Cooke, 2004). Additionally, MNEs influence environmental developments in terms of air and water pollution, climate change, resource consumption, and carbon dioxide emissions (Dunning \& Fortanier, 2007).

The role of MNEs in contributing to host country development has been discussed controversially, specifically in less developed countries. One extreme viewpoint emphasizes the negative effects, like crowding out local firms, abuse of powerful economic position or excessive profit repatriation (Kolk, van Tulder \& Wesdijk, 2006; De Backer \& Sleuwagen, 2003). The other extreme argues that MNEs as big global players should solve big problems and hence are expected to account for local and regional development (Hill, 2012; Prahalad \& Hammond, 2002).

Consequently, complementarity, responsibility and value creation are key success factors for MNEs in achieving sustainable development. Both interests of MNEs and host countries must be fully considered, as well as complementary purposes carved out, and responsible behavior stipulated in order to reach value creation (Yin \& Jamali, 2016). The SDGs are useful guidelines for MNEs in this endeavor.

\section{The Case of Huawei}

Huawei Technologies Corporation is a leading global provider of information and communications technology (ICT) infrastructure and smart devices. With integrated solutions across four key domains, telecom networks, IT, smart devices, and cloud services, it is committed to bringing digital to every person, home and organization for a fully connected, intelligent world. In 2017, Huawei had more than 180,000 employees worldwide, including 40,000 non-Chinese, operated in more than 170 countries and regions worldwide, and had revenues of 92.55 bn USD with net profits of 7.28 bn USD (www.huawei.com). Founded in 1987 in Shenzhen (China) as a just small distributor of imported products, Huawei grew rapidly and became a global giant. It is a private company fully owned by its employees (Guo et al., 2018).

Huawei's entry into international markets was initially limited to developing countries especially in South-East Asia, Africa and Latin America. It began with Russia in 1997, followed by Thailand, Indonesia, South Africa, Tanzania, Brazil, Mexico, and Venezuela. The company then sought international growth into Middle Eastern nations, like Saudi Arabia, Bahrain and Jordan. In 2012, Huawei set up an office in the United States and 
made its first two major sales in Europe - the Netherlands and Germany (Luo et al., 2011). Through internationalization, Huawei has learned to compete effectively by adjusting its mechanisms, learning instruments and focal points (Low, 2007). While in 2005, Huawei's international contract orders exceeded domestic sales for the first time, just 10 years later it ranked number 3 in the global smartphone market only behind Apple and Samsung (www.huawei.com).

Huawei is besides Lenovo, ZTE, TCL, and Haier, one of the Chinese enterprises that intensely and successfully engaged in foreign direct investment (FDI) in both developed and developing countries, particularly after 2001 when the Chinese government implemented its Go Global Policy (Cui \& Jiang, 2012). Much of these FDI activities of Chinese enterprises led to discussions and controversial views about benefits and exploitation (Clegg \& Voss, 2018). Against this background, a detailed look at Chinese MNEs' international engagements in the context of sustainable development brings novel and interesting insights on the relationship between business and sustainability.

\section{Huawei and Sustainability}

Sustainability is a topic of high importance to Huawei as it is explicitly emphasizing the concepts of value creation ("Through open collaboration with ecosystem partners, we [Huawei] create lasting value for our customers, working to empower people, enrich home life, and inspire innovation in organizations of all shapes and sizes."), economic growth ("Huawei generates tax revenues, provides local employment opportunities, and stimulates the development of the ICT value chain in every country where we operate. Furthermore, we deliver innovative ICT solutions that drive the digital transformation of all industries, fostering economic growth and greatly improving quality of life."), and responsibility ("As a responsible corporate citizen, Huawei has made a significant contribution to bridging the digital divide, leaving our mark in places as remote as Mount Everest and the Arctic Circle." www.huawei.com/us/about-huawei/corporate-information).

\subsection{Products / Services and sustainable development}

Huawei's vision for sustainability is to "Connect the Future" (www.huawei.com). This is translated into ICT products and services that bridge the digital divide, support network stability and security, as well as make the world greener, and hence enable economic and social progress and sustainability. Some examples of sustainable products and services are listed below.

First, Huawei's smart phones and devices are of such design that they minimize energy consumption and carbon emission. Throughout their product lifecycle, from selection of raw materials, manufacturing, packaging, transportation to disposal, rigorous controls are implemented. Environmentally friendly materials, like bioplastic and soy ink, minimized and green packing, or recyclable waste are used, and thereby mainly contribute to SDG 12 (Responsible consumption and production) and 3 (Good health and well-being).

Further, Huawei's data center switches and enterprise networks bring ICT benefits to companies and communities alike. Challenges in rural networks, public safety, health care, transportation, retail logistics, and education can be addressed. One example where Huawei brought fast broadband services to rural areas included Thailand, Ghana and Mexico, which cut access costs, increased network coverage immensely, and also enabled 
distance education. SDG 8 (Decent work and economic growth) and 4 (Quality education) are thus approached.

Finally, Huawei's cloud computing and big data solutions support affordability and efficiency of digital transformation, for instance for upgrading power grid or supply chain management, or monitoring earthquakes. Making cities safer and more sustainable, and providing mobile money solutions for areas where banking services are unavailable are further examples how Huawei contributes to SDG 9 (Industry, innovation and infrastructure) and 11 (Sustainable cities and communities). Table 1 gives a summary of Huawei's products and services, their contribution to the corresponding SDG, the developmental benefit and if applicable instancing countries.

Table 1: Huawei's products and services and their contribution to SDGs

\begin{tabular}{|c|c|c|c|}
\hline SDG & Product / Service & Developmental benefit & Country \\
\hline SDG 3 & $\begin{array}{l}\text { Health products, } \\
\text { wearables, smart } \\
\text { devices }\end{array}$ & Health monitoring, eye-protection mode & More than 75 countries \\
\hline SDG 4 & Campus switches & $\begin{array}{l}\text { Cloud classroom, distance learning, } \\
\text { research networks }\end{array}$ & $\begin{array}{l}\text { e.g., Slovakia, Turkey, } \\
\text { Kazakhstan, Ethiopia, Saudi } \\
\text { Arabia, UAE }\end{array}$ \\
\hline SDG 8 & Routers, Servers & $\begin{array}{l}\text { Digitalization, reliable networks, high } \\
\text { speed, secure, wireless, indoor \& outdoor } \\
\text { applications }\end{array}$ & $\begin{array}{l}\text { e.g., Brazil, Russia, Czech, } \\
\text { Philippines, Cameroon, Kenya }\end{array}$ \\
\hline SDG 9 & $\begin{array}{l}\text { Cloud computing, } \\
\text { Big Data solutions }\end{array}$ & $\begin{array}{l}\text { Resource pooling, industry digital } \\
\text { transformation, Internet of Things (IoT) }\end{array}$ & $\begin{array}{l}\text { e.g., India, Chile, Pakistan, } \\
\text { Poland }\end{array}$ \\
\hline SDG 11 & $\begin{array}{l}\text { Data center switches, } \\
\text { enterprise networks }\end{array}$ & $\begin{array}{l}\text { Stable networks, public WiFi, real-time } \\
\text { analysis }\end{array}$ & $\begin{array}{l}\text { e.g., Poland, Malaysia, Russia, } \\
\text { Ghana }\end{array}$ \\
\hline SDG 12 & $\begin{array}{l}\text { Smart phones, smart } \\
\text { devices }\end{array}$ & $\begin{array}{l}\text { Safe, green products, renewable, energy } \\
\text { efficient, recyclable }\end{array}$ & More than 75 countries \\
\hline
\end{tabular}

\subsection{Business operations and sustainable development}

Regarding business operations, Huawei targets to establish an outstanding sustainability management system, operate with integrity and compliance, and promote responsible business growth (www.huawei.com). Therefore, its sustainability strategy is implemented in numerous safe, green and deliberate operations. Next, follow some examples of sustainable business operations.

For integrating sustainability requirements into business operations, Huawei has established a sustainability management system based on international standards, like ISO 14001, ISO 26000 and OHSAS 18001. The topics of environmental resource management, corporate social responsibility (CSR), and health and safety management are thereby addressed. Thus, Huawei contributes to SDG 8 (Decent work and economic growth) and 13 (Climate action).

Moreover, in 2017 at the Annual Meeting of the World Economic Forum, Huawei and more than 100 leading MNEs signed "The Compact for Responsive and Responsible Leadership" (https://www.weforum.org). This means a commitment to sustainable long-term growth, the collaboration of MNEs, shareholders and other stakeholders, transparent and respectful cooperation, mutual trust and effective stewardship. Again, SDG 8 (Decent work and economic growth) is the related sustainable goal here.

Furthermore, for caring for its employees, Huawei provides a comprehensive welfare 
security system, professional healthcare services, fair access to learning and promoting opportunities, irrespective of gender, age, religion or nationality, as well as a safety assurance system. Another priority is given to hire local employees, which resulted in a localization rate of over $71 \%$ in 2016. Huawei wants to serve as a role model for employee-oriented operations, which contributes, to SDG 3 (Good health and wellbeing).

Additionally, as a member of the United Nations Global Compact, Huawei is committed to ethical procurement and support of sustainable supply chain management (https://www.unglobalcompact.org/participation/report/cop/create-and-

submit/detail/5862). One example is Huawei's engagement in improving the upstream cobalt supply chain for lithium-ion batteries. It requires suppliers to ensure that they protect human rights, reasonably prevent and reduce handling risks, and exercise measurable due diligence over the sourcing and chain of custody of this mineral. Therefore, Huawei contributes to SDG 12 (Responsible consumption and production), 13 (Climate action) and 8 (Decent work and economic growth).

Similarly, Huawei developed a "Supplier Social Responsibility Code of Conduct". In response to the needs of their customers, it requires suppliers to comply with all applicable laws and regulations as a prerequisite for cooperation with Huawei. Huawei incorporates CSR into every phase of the procurement process, from materials qualification, supplier qualification, performance evaluation and phase-out. CSR is an integral aspect in supplier performance evaluation. Thereby, Huawei again makes for SDG 8 (Decent work and economic growth), 12 (Responsible consumption and production) and 13 (Climate action). Table 2 shows some examples of Huawei's initiatives to integrate sustainability into its business operations.

Table 2: Huawei's business operations and their contribution to SDGs

\begin{tabular}{|l|l|l|}
\hline SDG & Business operation & Developmental benefit \\
\hline $\begin{array}{l}\text { SDG 8, } \\
13\end{array}$ & $\begin{array}{l}\text { Uustainability Management System based } \\
\text { on ISO 14001, ISO 26000, OHSAS 18001 }\end{array}$ & $\begin{array}{l}\text { Environmental resource management, corporate } \\
\text { social responsibility, health and safety management }\end{array}$ \\
\hline SDG 8 & $\begin{array}{l}\text { The Compact for Responsive } \\
\text { and Responsible Leadership, } \\
\text { World Economic Forum }\end{array}$ & $\begin{array}{l}\text { Focus on long-term economic and social } \\
\text { prosperity, collaboration of all stakeholders, } \\
\text { transparency and respect }\end{array}$ \\
\hline SDG 3 & $\begin{array}{l}\text { Employee welfare security system, iHealth } \\
\text { centers, safety assurance system }\end{array}$ & $\begin{array}{l}\text { Safe workplace, access to health services, } \\
\text { emergency treatment }\end{array}$ \\
\hline $\begin{array}{l}\text { SDG 12, } \\
13,8\end{array}$ & $\begin{array}{l}\text { UN Global Compact member; } \\
\text { responsible cobalt supply chain }\end{array}$ & $\begin{array}{l}\text { Protect the environment, secure health, safety, and } \\
\text { human rights }\end{array}$ \\
\hline $\begin{array}{l}\text { SDG 8, } \\
12,13\end{array}$ & $\begin{array}{l}\text { Supplier Social Responsibility } \\
\text { Code of Conduct }\end{array}$ & $\begin{array}{l}\text { Labor, Health \& Safety, Environment, Business } \\
\text { Ethics, Management Systems, responsible sourcing }\end{array}$ \\
\hline
\end{tabular}

\subsection{Social contributions and sustainable development}

Huawei wants to proactively fulfill its social responsibility as a strong contributor and responsible corporate citizen in all local communities in which it operates. Via collaboration with all sectors of society, Huawei seeks to promote socioeconomic growth and improve the environment by leveraging its ICT expertise and management experience to roll out social contribution projects. Five examples of Huawei's CSR and local community support projects are presented below. 
First, in 2008, Huawei initiated the "Seeds for the Future Program", a global program for university students to learn about China, to experience Huawei's dynamic global business, and gain a deeper understanding of current topics of the ICT sector. By the end of 2017, the "Seeds for the Future Program" had over 30,000 students from more than 350 universities worldwide from 108 countries and regions as participants and a total of 3,600 top college students have been able to visit and study at Huawei's headquarters in China. The main aims of this program are to develop local ICT talent, and enhance knowledge transfer, and thus contributes to SDG 4 (Quality education).

Second, Huawei established local Training Centers in more than 40 countries that deliver courses in 16 languages. Over 200 full-time engineers and over 1,200 full-time and parttime trainers design and deliver ICT courses live and online. By providing a global standard training environment for local trainees on new generation computing, telecommunication and related technologies ICT skills are built amongst employees and key players in the local ICT ecosystem. This can drive the ICT industry and the countries' digital transformations and therefore contributes to SDG 4 (Quality education) and 9 (Industry, innovation and infrastructure).

Third, Huawei develops and implements "Smart City " solutions in 40 countries. These include for instance, ecosystem software, IoT, Geographic Information systems, Big Data, cloud computing and virtualization. These solutions help enhance municipal management, improve government services, and promote the development of industry and the people through Intelligent Traffic Monitoring, Smart Parking, Smart Campus, Smart Transport and Smart Water Management. This adds to SDG 11 (Sustainable cities and communities), 13 (Climate action) and 7 (Affordable and clean energy).

Forth, Huawei provides advise and insight into how new progress in technology like 5G, IoT, and cloud can help advance the economy to many governments. This resulted for example in developing a digital economy whitepaper, and driving the growth of sectors like agriculture, tourism, and public health through direct government investment and the promotion of indirect social investment. In addition, support of the digital transformation of national governments, including plans for a unified government cloud, improves the efficiency of public services, enhances data security, and reduces overall costs. Huawei's government advisory accounts for SDG 11 (Sustainable cities and communities) and 8 (Decent work and economic growth).

Finally, Huawei aims to support the ICT sectors in all countries it operates and wants to give back to local communities and bring direct benefits to local people. In 2016, Huawei run more than 200 community support programs in 70 countries and regions. Local issues are directly addressed and living standards are improved, education for refugees enabled, or underprivileged groups are supported. Initiatives include for example donations of food and other essentials, building of temporary shelters in case of natural disasters, or donations to first aid agencies, like the Red Cross. These social programs contribute to SDG 1 (No poverty), 3 (Good health and well-being), 9 (Industry, innovation and infrastructure), 10 (Reduced inequalities) or 13 (Climate action). Table 3 summarizes the exemplary social contributions of Huawei and their related SDGs. 
Table 3: Huawei's social contribution and their share to SDGs

\begin{tabular}{|c|c|c|c|}
\hline SDG & $\begin{array}{l}\text { Social } \\
\text { contribution }\end{array}$ & Developmental benefit & Country \\
\hline SDG 4 & $\begin{array}{l}\text { Seeds for the } \\
\text { future }\end{array}$ & $\begin{array}{l}\text { Cultivate local ICT talents, enhance } \\
\text { knowledge transfer, cooperate with local } \\
\text { universities }\end{array}$ & $\begin{array}{l}108 \text { countries and regions, e.g. } \\
\text { Bulgaria, Algeria, Lebanon, Benin, } \\
\text { Ecuador }\end{array}$ \\
\hline $\begin{array}{l}\text { SDG 4, } \\
9\end{array}$ & Training Center & $\begin{array}{l}\text { Support education, nurture local } \\
\text { professionals, drive a country's digital } \\
\text { transformation }\end{array}$ & $\begin{array}{l}\text { More than } 40 \text { countries, e.g. Kenya, } \\
\text { South Africa, India, Philippines, } \\
\text { Kuwait }\end{array}$ \\
\hline $\begin{array}{l}\text { SDG 11, } \\
13,7\end{array}$ & Smart City & $\begin{array}{l}\text { IoT solution reduce electricity usage, } \\
\text { better connected public facilities, smart } \\
\text { road traffic management \& healthcare }\end{array}$ & $\begin{array}{l}\text { In } 40 \text { countries, e.g. Bolivia, Zambia, } \\
\text { Mozambique, Angola, Laos, Serbia }\end{array}$ \\
\hline $\begin{array}{l}\text { SDG 11, } \\
8\end{array}$ & $\begin{array}{l}\text { Government } \\
\text { advisory }\end{array}$ & $\begin{array}{l}\text { ICT solutions help government services, } \\
\text { government-to-business clouds, digital } \\
\text { public services, help economic growth }\end{array}$ & $\begin{array}{l}\text { e.g., Brazil, Uganda, Saudi Arabia, } \\
\text { Singapore, Malaysia, Thailand }\end{array}$ \\
\hline $\begin{array}{l}\text { SDG } 1 \\
3,9,10 \\
13\end{array}$ & $\begin{array}{l}\text { Community } \\
\text { support }\end{array}$ & $\begin{array}{l}\text { Improve living standards, support } \\
\text { underprivileged groups, reinforce social } \\
\text { integration \& cultural exchange }\end{array}$ & $\begin{array}{l}\text { e.g., Tanzania, Ghana, Nigeria, } \\
\text { Mongolia, Venezuela, Morocco, } \\
\text { Yemen }\end{array}$ \\
\hline
\end{tabular}

\section{Conclusion}

The aim of this paper was to investigate the relationship between business and sustainable development, particularly the role of MNEs as possible driving force for achieving sustainability. By using Huawei as a case and referring to the SDGs of the UN, the main findings indicate that MNEs can promote sustainable development internationally on three different levels: (1) products/services, (2) business operations and (3) social contributions. The respective main stakeholders are customers, employees and communities. The compatibility of success in business with sustainability, as well as the key role of responsibility and value creation are clearly carved out. The following systematic framework describes how MNEs can contribute to sustainable development (Figure 2). As there is no hierarchy of these three levels, the framework is applicable to diverse MNEs irrespective of their size, age, international experience, home country or industry they are active in.

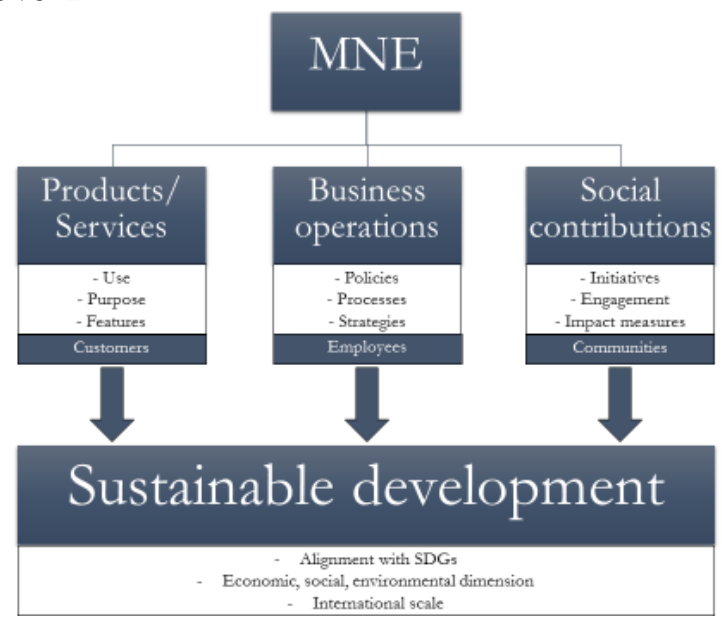

Figure 2: Framework for classifying MNE's sustainable activities 


\section{References}

Ambec, S. \& Lanoie, P. (2008). Does it pay to be green? A systematic overview. Academy of Management Executive, 22(4), 45-62.

Bryson, J.R. \& Lombardi, R. (2009). Balancing product and process sustainability against business profitability: sustainability as a competitive strategy in the property development process. Business Strategy and the Environment, 18, 97-107.

Clegg, L.J. \& Voss, H. (2018). Chinese Outward FDI as stimulus to research in international business. Management International Review, 58(1), 1-8.

Cooke, B. (2004). The managing of the (third) world. Organization, 11(5), 603-629.

Cui, L. \& Jiang, F. (2012). State ownership effect on firms' FDI ownership decisions under institutional pressure: a study of Chinese outward-investing firms. Journal of International Business Studies, 43(3), 264-284.

De Backer, K. \& Sleuwagen, L. (2003). Does foreign direct investment crowd out domestic entrepreneurship? Review of Industrial Organization, 22(1), 67-102.

Dunning, J.H. \& Fortanier, F. (2007). Multinational Enterprises and the New Development Paradigm: Consequences for Host Country Development. Multinational Business Review, 15(1), 25-46.

Eccles, R.G. \& Serafeim, G. (2013). A tale of two stories: sustainability and the quarterly earnings call. Journal of Applied Corporate Finance, 25(3), 66-77.

Elkington, J. (1997). Cannibals with forks: The triple bottom line of 21st century business. Oxford: Capstone Publishing.

Guo, L., Zhang, M., Dodgson, M., Gann, D. \& Cai, H. (2018). Seizing windows of opportunity by using technology-building and market-seeking strategies in tandem: Huawei's sustained catch-up in the global market. Asia Pacific Journal of Management, DOI 10.1007/s10490-018-9580-1.

Hall, J., Daneke, G. \& Lenox, M. (2010). Sustainable development and entrepreneurship: Past contributions and future directions. Journal of Business Venturing, 25(5), 439-448.

Hart, S. (1995). A natural resource-based view of the firm. Academy of Management Review, 20(4), 966-1014.

Hill, C. (2012). International Business. 9th edition. New York, NY: McGraw-Hill/Irwin.

Jensen, O. (2010). Social mediation in remote developing world tourism locations - the significance of social ties between local guides and host communities in sustainable tourism development. Journal of Sustainable Tourism, 18(5), 615-633.

Kolk, A. (2016). The social responsibility of international business: From ethics and the environment to CSR and sustainable development. Journal of World Business, 51(1), 23-34.

Kolk, A., van Tulder, R. \& Wesdijk, B. (2006). Poverty alleviation as business strategy? Evaluating commitments of frontrunner multinational corporations. World Development, 34(5), 789-801.

Low, B. (2007). Huawei Technologies Corporation: from local dominance to global challenge? Journal of Business \& Industrial Marketing, 22(2), 138-144.

Lowe, N. \& Kenney, M. (1999). Foreign investment and the global geography of production: Why the Mexican consumer electronics industry failed. World Development, 27(8), 1427-1443.

Luo, Y., Cacchione, M., Junkunc, M. \& Lu, S. (2011). Entrepreneurial pioneer of international venturing. The case of Huawei. Organizational Dynamics, 40(1), 67-74.

Milne, M.J. \& Gray, R. (2013). W(b)ither Ecology? The triple bottom line, the global reporting initiative, and corporate sustainability reporting. Journal of Business Ethics, 118(1), 13-29.

Oetzel, J \& Doh, J.P. (2009). MNEs and development: a review and reconceptualization. Journal of World Business, 44(2), 108-120.

Orlitzky, M., Schmidt, F. \& Rynes, S. (2003). Corporate social and financial performance: A meta-analysis. Organization Studies, 24(3), 403-441.

Prahalad, C.K. \& Hammond, A. (2002). Serving the world's poor, profitably. Harvard Business Review, 80 (9), 48-59.

Rodriguez, M., Ricart, J. \& Sanchez, P. (2002). Sustainable development and the sustainability of competitive advantage: a dynamic and sustainable view of the firm. Creativity and Innovation Management, 11(3), 135-146.

Siegel, S. (2009). Green management matters only if it yields more green: an economic/strategic perspective. Academy of Management Perspectives, 23(3), 5-16.

Yin, J. \& Jamali, D. (2016). Strategic Corporate Social Responsibility of Multinational Companies Subsidiaries in Emerging Markets: Evidence from China. Long Range Planning, 49(5), 541-558. 